ISSN: 2414-0325. Open educational e-environment of modern University, special edition (2019)

\author{
Vladyslav Bilous \\ Manager of cabinet of laboratory of the embedded systems and 3D design \\ Borys Grinchenko Kyiv University, Kyiv, Ukraine \\ v.bilous@kubg.edu.ua \\ ORCID: 0000-0001-6915-433X
}

\title{
BASIC PRINCIPLES FOR DEVELOPING AN ADAPTIVE LEARNING SYSTEM
}

\begin{abstract}
The work focuses on the basic principles of developing an adaptive learning system. The modern concept of open education assumes multilevel character of training, and also possibility of a choice of means, a place and time of training corresponding to its inquiries by trainees. This implies the availability of alternative teaching aids (courses) and application software for their creation, support of training and adaptation to a particular student. A significant challenge is to reduce the cost of developing e-learning courses and to increase their use in online learning. In addition, despite the availability of automated tools to simplify the development of pedagogical rules, it is impossible to generate rules suitable for any situation. These reasons have led to the search for a solution to the problem of developing e-learning courses that implement adaptive learning. The principles laid down in the concept of designing such a system are formulated. The structure of the system, including the model of the subject area (educational content), the model of the user, the model of adaptation and the model of evaluation of learning outcomes are presented. Within the framework of the proposed system, it has been developed and is at the testing stage. It is justified that the successful use of such a system by students contributes to the formation of their specific competences. In the adaptive system the roles of a teacher and a trainee are changing: a teacher is an organizer of the initial activities, and the responsibility for the results is shared with students. In this system, the democratic management style, not authoritarian one, is taken into account. A student is a performer of educational process and not a passive recipient of information (an object of the process). With the help of a teacher they acquire knowledge, actively involve into thinking process and plan own educational and cognitive activity. The central place in the adaptive learning system is occupied by a student with their individual features: biological potential and abilities, specifics of the organization of the cognitive process, the level of activity and independence in practical and cognitive activity, as well as efficiency, etc. The result of this system is a qualitative change in their individual features. Active independency of a student in the process of cognitive activities promote the development of individual qualities, the formation of intellectual and spiritual growth, as well as self-knowledge of a learner's personality. This is the way the system is adapted to the formulation of competence of individual self-improvement.
\end{abstract}

Keywords: adaptive learning system; traditional learning system; education; pedagogy; psychology; methods of adaptive learning system

Introduction. Active development of information and communication technologies has a great impact on the global education system. Traditional educational technologies are being replaced by e-learning, actively developing. The active use of e-learning courses in teaching the modern "digital generation" living in the world of electronic culture, applies to all disciplines in educational institutions.

It should be noted, however, that the organization of training in the electronic environment is a difficult pedagogical and instrumental-technical task. This is due, in particular, to the fact that e-learning methodologies are not yet sufficiently developed. In addition, the implementation of e-learning, unlike traditional e-learning, does not provide for direct participation in the educational process of the teacher, taking into account the individual characteristics of the learner. We believe that this teaching function can be greatly enhanced by an adaptive e-learning course.

Taking as a basis the definition of the electronic educational resource given in the national standard of Ukraine, under the adaptive electronic training course of disciplines we understand the educational resource presented in the electronic-digital form and including the structure and the subject content, which allows the possibility of adaptation for students depending on their 
individual characteristics. The use of adaptive e-learning courses in the learning process helps to personalize learning and increase its effectiveness. It should be noted that ensuring personalization of education is a global trend in modern education.

The purpose of the article is to build a mobile adaptive learning system in an electronic environment, the description of the structure and components of this system, as well as the principles of its development.

Within the framework of the proposed system, a mobile adaptive learning system is being developed for the popular Android mobile platform.

A specific feature of the current stage of education development is the transition from traditional education to new pedagogical directions, which create a favorable environment for the development of a fully developed personality.

Modern didactics has a large number of pedagogical innovations that take into account the social demands of society. Examples include models of full assimilation (J. Carroll, B. Bloom), programmed learning (N. Crowder, B. Skinner, S. Pressy), person-centered learning technology (Y. Malashchenko), modular learning (J. Russell), developing learning (L.S. Vygotsky), etc. The adaptive system of education has also gained a certain popularity in the national pedagogy. It was formed at the intersection of the theory of gradual formation of mental actions and the activity approach to learning. Features of the use of this system can be presented in the works of N. Morse, O. Spirin, V. Bykov, M. Zhaldak, etc.

Adaptive learning involves a flexible system of training sessions tailored to the individual characteristics of the learners. Special attention is paid to the learner, his or her activity, the qualities of his or her personality and the formation of his or her learning skills. When applying an adaptive learning system, the teacher must clearly understand what tasks can be accomplished by using it. In addition, the educator should take into account the age characteristics of the students.

Taking into account the humanistic approach, adaptive technology provides a differentiated approach to learning, taking into account the level of intellectual development of the student, his level of training and abilities. In particular, the adaptive learning technology proposed and implemented in the educational process is based on independent work, selfcontrol, design and research activities aimed at developing and improving the skills of independent work for intellectual activity and formation of basic competences. The proposed technology is aimed at maximum adaptation of the educational process to the individual features and needs of students. The essence of adaptive technology is the simultaneous work of the teacher to manage the independent work of all students, work with individual students (individually), accounting and implementation of individual characteristics of students in the learning process, the maximum involvement of all students in the individual.

Taking into account the informatization of education and peculiarities of the modern educational process, it is expedient to apply information and educational systems based on adaptive technologies of education in the educational process. (Brusilovsky, 1998, pp. 1 - 43).

Ideas of adaptive learning in the environment of information systems, provides for the creation of conditions for individualization of learning, differentiation of tasks, taking into account the individual educational needs of students, were first discussed in the works of $\mathrm{G}$. Easter and A. Berg. Scientists have investigated adaptive learning as the creation of an adaptive mechanism to manage the activities of the subject of learning, which supports interest, attention and motivation.

An adaptive learning system using information systems has a number of advantages, including:

1. provides students with a wide range of opportunities to choose their own learning trajectory of mastering a certain topic: the choice of individual pace of study, level, 
period of mastering educational material, planning of independent and individual work, etc;

2. provides a differentiated approach based on the fact that different students have different experience and level of knowledge on a certain topic, each student learns the educational material of the topic in accordance with this level of knowledge and depending on its individual type of perception (visual, audio or kinesthetic) and the pace of learning, that is, the transition of the learning system from the study of the same material by students to the study of different material by different students;

3. increases the efficiency and objectivity of monitoring and evaluation of learning outcomes;

4. includes diagnostic monitoring of the topic and correction of the training trajectory according to individual characteristics;

5. promotes individualization of learning activities (differentiation of the pace of learning, complexity of learning tasks, type of learning tasks, etc.);

6. increases cognitive motivation;

7. promotes the development of productive, creative thinking functions in students, the growth of individual abilities, etc;

8. creates conditions for partnership and cooperation between students and the instructor. Here is an example of the roles of a student and a teacher in adaptive learning (Table 1).

Table 1.

Teacher and student roles in adaptive learning

\begin{tabular}{|c|c|}
\hline Teacher & $\begin{array}{l}\text { Student. } \\
\end{array}$ \\
\hline Organizer of cognitive activities of students & $\begin{array}{l}\text { The subject of the training, with the help of } \\
\text { a teacher, obtains knowledge }\end{array}$ \\
\hline $\begin{array}{l}\text { Directs the cognitive process, providing } \\
\text { independent activity of students within the } \\
\text { framework of social interaction }\end{array}$ & Included in the active thinking process \\
\hline $\begin{array}{l}\text { Democratic style of relations dominates, } \\
\text { based on cooperation, cooperation }\end{array}$ & $\begin{array}{l}\text { An active participant in the pedagogical } \\
\text { process in which self-fulfillment and self- } \\
\text { affirmation take place }\end{array}$ \\
\hline $\begin{array}{l}\text { Shares responsibility for the results of the } \\
\text { educational process with students }\end{array}$ & $\begin{array}{c}\text { Included in the responsibility for the results } \\
\text { of the learning process, being aware of their } \\
\text { importance for their promotion and } \\
\text { development }\end{array}$ \\
\hline Motivational training is provided & Internal motivation dominates \\
\hline $\begin{array}{l}\text { The dominant methods of independent } \\
\text { work, brainstorming }\end{array}$ & $\begin{array}{l}\text { Performs research work, applying } \\
\text { knowledge in similar and changed situations }\end{array}$ \\
\hline $\begin{array}{l}\text { Uses reflexive management of students' } \\
\text { cognitive activities }\end{array}$ & $\begin{array}{c}\text { Included in self-reflection, self-assessment } \\
\text { of thinking activities }\end{array}$ \\
\hline
\end{tabular}

Therefore, Table 1, it would be correct to describe the lesson in more detail in an adaptive learning system, taking into account the presence of students with "mixed abilities".

1. All subjects are taught in "mixed ability" groups because, with rare exceptions, we cannot identify children's aptitudes so early. That's why, speaking out against early external differentiation of education, we prefer to differentiate it internally, through specially organized remedial and development work and selection of pedagogical technologies for a specific student.

2. Presentation of educational material in portions. 
3. Diagnostic tests to identify the success of students' acquisition of learning material at the end of the basic unit of study. Those who have learned are offered additional, enriched material. Those who have not mastered the main content are encouraged to reexamine the corrected material.

4. Organization of work on tasks individually or in groups during the correction or additional period.

5. Correction or additional groups are allocated within the class.

6. Special attention is paid to working with a small group of children and individual differentiation.

7. All students start studying the new basic unit at the same time.

8. Fixing an understanding of the knowledge requirements of the students in the absence of any time limits for the study of a particular base unit.

9. Diagnostic testing as the most important feature of this model.

10. Models of good functioning of attention as a condition of student management, because children must acquire skills of working in a group.

11. Ensuring good relations between students and the working environment of the classroom, with constant regrouping as a condition for effective learning.

The problem of adaptive learning in modern information training systems is considered in methodological and technical aspects. In particular, planning and organization of the educational process, determination of types of tasks, levels of their complexity, the sequence of presentation of the material, the conduct of various types of control: preliminary, current, periodic, final, self-monitoring, the definition of criteria for evaluating each type of task are referred to the methodological aspects of adaptive learning in information training systems. (Brusilovsky, Peylo, 2003, pp. 159-172).

Technical aspects include:

1. An algorithm that proposes to move to a new level when most tasks are completed correctly, or to return to the previous level, taking into account mistakes made during the execution of tasks;

2. The algorithm of forming a number of tasks in accordance with the level of knowledge of the student;

3. An algorithm for evaluating students' academic achievements, and so on.

Let us consider the methodological aspects of adaptive learning in the information learning system.

The principle of adaptability of education in modern information and training systems is aimed at building individual educational programs, aimed at psychological correction of the stereotype of a person's actions, his thinking and mechanisms of implementation.

The main didactic principles of adaptive learning in modern information systems are the principles of activity, independence, individuality, consistency and consistency.

1. The principle of activity assumes that the activity based on adaptive technology should contribute to the development of students' skills not only to solve problems according to a given algorithm, but also to independently build algorithms for performing creative tasks.

2. The principle of independence is expressed in the fact that students are able to navigate independently in new topics, think independently and find algorithms to perform new tasks.

3. The principle of individuality implies individualized ways of interaction between the student and the teacher. The use of adaptive learning based on this principle, taking into account the individual characteristics of the student, contributes to the formation of a high level of intellectual development. 
4. The principle of consistency and consistency implies a logical, consistent formation of knowledge, skills and knowledge from both the same topic and the logical connection between different topics.

An information training system for adaptive learning should have a number of features:

1. The information system should provide the conditions for achieving learning objectives;

2. The information system should include a combination of different types of presentation of training data aimed at individual characteristics of material perception (visual, auditory or kinesthetic);

3. The information system must be adapted to the different forms and methods of learning.

Thus, in an adaptive learning system, the teacher includes all students in the learning process, regardless of their abilities and aptitudes, and differentiation occurs only internally, on the basis of diagnostic testing, through individual and group corrective and developmental work. Internal differentiation allows for a number of years not to break the existing teams, which is certainly an additional health-saving factor. In addition, there is an opportunity, based not only on testing, but also on years of pedagogical observation of students, to identify who will feel comfortable in the traditional cognitive paradigm of education, in the conditions of increasing its content, and who will be better educated in the affective-emotional-volitional paradigm. (Devedžić, 2004, pp. 29-39).

We offer a concept of adaptive learning in an electronic environment based on the following principles

1. Personalization - providing personalization of the educational process in the electronic environment, allowing the student to build an individual educational trajectory and create an individual space for learning materials;

2. Content variability - learning content has different forms of representation;

3. Cyclicality of learning - automatic return to the material of the studied topic presented in another form;

4. Filling in gaps in knowledge and skills previously acquired;

5. Motivational and intellectual involvement of students in the learning process;

6. Aiming to achieve learning outcomes;

7. Integrity - the formation of a holistic perception of the discipline by students;

8. Relevance - the content of the training is relevant to the learners and is in the context of their future professional activities;

9. The trainer does not act as a translator of knowledge, but organizes, manages and advises students.

These principles are implemented in the construction of an adaptive learning system in an electronic environment, which consists of a model of the subject area, a user model, an adaptation model and a model for assessing learning outcomes.

When including the concepts in the term, we apply the following criteria in our microtraining strategy:

1. Volume limitation - each term contains no more than five concepts; if the concept is information-rich, it can be distinguished in a separate term;

2. Completeness - the principle of investing small structural units in large ones is implemented in the formation of the term, i.e., along with the concept of small volume, smaller concepts are included;

3. Verifiability - all concepts of the term allow the possibility to check their assimilation.

The individual characteristics of the learners are described in two groups of parameters. The first group includes the student's learning style and the results of each term. The second group of parameters includes the results of monitoring the learning process of the student in the electronic environment: his current position, the time spent on the study of the terms and tasks, 
the number of effective logins to the system, which allows the teacher to manage the activities of the student.

Thus, the user's model allows taking into account the individual parameters of the student, as well as the need for personal support for him/her by the teacher. (Bykov, 2008).

The model of adaptation of the training system in the electronic environment includes an automated navigation system and adaptation of training content taking into account the individual characteristics of the trainee. Each element of the learning content (thermo material, test or task) has its own settings depending on the capabilities of the learning management system.

To adapt the learning content, three versions of each term are provided, which differ in their level of detail and presentation: text, graphics, tables, audio and video materials, and interactive resources. On the basis of experimental data it is established that three versions of the terms are enough to master the discipline material and achieve the required learning outcomes.

When studying the current term, the student has access to the educational material in the version corresponding to its current parameters in the user model. The first term is selected based on the results of the input testing. Specifically, students with low scores have access to the third level editorial office, students with average scores have access to the second level editorial office, and students with high scores have access to the first level editorial office.

After studying the material of the thermo in the automatic mode the transition to the check of its assimilation is carried out in the form of testing. If the result reaches the threshold in the first attempt, this allows the student to move on to the next term. At the same time, the student may decide to improve his or her performance. He has access to the material term in another version of the presentation, after which he is tested again. If both attempts are unsuccessful, the student will seek advice from the teacher. Aggregated algorithm of transition from one term to another.

The learning process organized in this way leads to the formation of the individual educational trajectory of the student and his or her individual learning materials space.

The model of assessment of learning outcomes in the adaptive system is designed to determine the level of formation of subject competence of a student through the assessment of all its components.

The following control and measurement materials have been developed for the evaluation of training results:

1. An entrance test designed to determine the individual characteristics of a student and his or her level of preparedness for mastering the discipline;

2. Thermal tests to test knowledge and understanding of current material;

3. Tasks for independent decision making with answers for forming skills;

4. Skills development tests, i.e. limited time to complete tasks;

5. Applied and professionally directed tasks designed to identify readiness to apply the knowledge gained in the future profession;

6. Tests for intermediate attestation for each module of the discipline;

7. The final test.

The process of evaluating learning outcomes is automated and begins with the control of the assimilation of the contents of the terms (cognitive component of competence), which is implemented through the performance of tests for terms. The ability to operate with concepts (activity component) is tested with the help of final tests on the modules of the discipline. Formed skills are confirmed by performing test simulators for a limited time. 
To assess the motivational component of competence, applied and professionally directed tasks are intended, the solution of which indicates the readiness of the student to apply the knowledge gained in the future profession. (Morze, Hlazunova, 2008).

To evaluate the reflexive component, all tests for terms have two attempts. After the first attempt, the student receives an immediate response to his or her decision. If there are any mistakes, he or she will reflect on them and will have the opportunity to be retested after studying the material in another version of the narrative.

As a result of evaluation of all components, it is possible to draw a conclusion about the level of formation of subject competence in the student's learning in the electronic environment. Thus, the developed system consisting of interconnected models of the subject area, user, adaptation and assessment of learning outcomes allows to implement adaptive learning in the electronic environment, as well as assess the level of formation of subject competence among students.

During the implementation of adaptive learning, the instructor (or group of instructors) develops educational content and acts as facilitator and coordinator of the learning process, monitors learning outcomes, manages impacts and advises students. Management actions include messages that set the standard pace of learning, gamification elements, task performance indicators and achievement ratings that help to increase motivation to learn. (Shyshkina, Spirin, Zaporozhchenko, 2012).

One of the important aspects of the organization of training in the electronic environment is the communication of students with each other and with the teacher, which is implemented by means of online and offline communication: forums, chat rooms, feedback mechanisms in the elements of the electronic course.

Conclusion. The author proposes a unique system of training in the electronic environment using all possible platform technologies. Methods and algorithms of adaptation of educational materials, structuring of the subject area in the form of a hierarchy of terms, as well as the model of assessment of learning outcomes, which provides an assessment of the level of formation of the subject competence of students. The proposed approach to building a model of the subject area is based on the integration and development of methods of logical and gnosiological analysis of concepts.

The development process has identified a number of benefits for both the learner and the teacher. Namely, the use of an adaptive system in the study of the discipline allowed each student to build an individual educational trajectory and to form a personal space of educational materials corresponding to his or her individual characteristics. Primary testing in the educational process gave the students an opportunity to organize a flexible study schedule with constant self-control of learning outcomes, to improve the quality of learning of the discipline. The survey among students has shown that learning with the use of adaptive learning system has contributed to the formation of a holistic perception of the discipline, increasing motivation to study it and minimizing psycho-emotional stress.

Also, according to the results of work in the adaptive system, students noted the following positive factors: the ability to study the material in a form that is easy to understand; improving the efficiency of classroom work, because the student comes to practical classes, knowing the theoretical material; the ability to engage in comfortable time and at their own, individual pace. At the same time, some students admitted that they had difficulties with self-organization. For the teacher, the introduction of an adaptive system in the educational process has reduced the volume of broadcast learning material and routine processing of learning outcomes. Although the system is labour-intensive and time-consuming, its use in the learning process has led to a reduction in the teacher's classroom workload and the release of hours that can be used for his or her professional development. 
During the testing, the required additions to the adaptive learning system were identified, or more precisely, when using smartphones based on Apple, Android, Tizen, Ubuntu OS, special library packages are required to work with multimedia. Each of these systems uses WEB 3.0, Flash technology based on PhoneGap, OpenCL 2.0, Box 2D, LibGDX, PhysX. For WEB technologies, HTML, PHP, JS, FLASH, WEBGl components are sufficient, for older versions of WEB Action Script 3.

\section{REFERENCES}

Brusilovsky, P. (1998). Methods and Techniques of Adaptive Hypermedia. Adaptive Hypertext and Hypermedia, 1-43. doi: 10.1007/978-94-017-0617-9_1

Brusilovsky, P., \& Peylo, C. (2003). Adaptive and Intelligent Technologies for Webbased Education. International Journal of Artificial Intelligence in Education, 13(2-4), 159172.

Devedžić, V. (2004). Intelligence and Artificial Intelligence in Education. Educational Technology \& Society, 7(4), 29-39.

Bykov, V. (2008). Modeli orhanizatsiynykh system vidkrytoyi osvity: monohrafiya. Atika. - 684 p. (in Ukrainian)

Morze, N., \& Hlazunova, O. (2008). Models of effective using information and communication and distance learning technologies in higher education. Informatsiyni Tekhnolohiyi i Zasoby Navchannya, 6(2). (in Ukrainian)

Shyshkina, M., Spirin, O., \& Zaporozhchenko, Y. (2012). Problems of information education of Ukraine in the context of development of ICT quality assessment studies. Informatsiyni Tekhnolohiyi i Zasoby Navchannya, 1(27). (in Ukrainian)

\section{ОСНОВНІ ПРИНЦИПИ РОЗРОБКИ АДАПТИВНОЇ СИСТЕМИ НАВЧАННЯ}

\section{Білоус Владислав Володимирович}

Завідувач кабінету лабораторії вбудованих систем та 3D-дизайну

Київський університет імені Бориса Грінченка, Київ, Україна

v.bilous@kubg.edu.ua

ORCID: 0000-0001-6915-433X

\footnotetext{
Анотація. Робота присвячена основним принципам розробки адаптивної системи навчання. Сучасна концепція відкритої освіти передбачає багаторівневий характер навчання, а також можливість вибору учнем засобів, місця і часу навчання, відповідних його запитам. Це має на увазі наявність альтернативних навчальних посібників (курсів) і прикладного програмного забезпечення для їх створення, супроводу навчання та адаптації до конкретного, якого навчають. Важливою проблемою є зниження вартості розробки електронних навчальних курсів і розширення можливостей їх використання в рамках мережевого навчання. Крім того, незважаючи на наявність автоматизованих засобів, що дозволяють спростити розробку педагогічних правил, неможливо згенерувати правила, які підходять для будь-якої ситуації. Перераховані фактори призвели до пошуку вирішення проблеми розробки електронних навчальних курсів, що реалізують адаптивне навчання. Сформульовано принципи, закладені в концепцію проектування такої системи. Представлена структура системи, що включає модель предметної області (освітнього контенту), модель користувача, модель адаптації та модель оцінки результатів навчання. В рамках запропонованої системи розроблений $і$ знаходиться на стадії тестування. Обгрунтовано, що успішне використання такої системи навчаються сприяє формуванню у них загально специфічних компетентностей. В адаптивній системі змінюються ролі вчителя і учня: учитель виступає організатором навчальної діяльності, а що стосується відповідальності за результати, то він розділяє їх з учнями. У цій системі перевага віддається демократичному стилю керівництва, а не авторитарного. Учень $\epsilon$ суб'єктом навчання, а не пасивним одержувачем інформації (тобто об'єктом). Завдяки вчителю він видобуває знання, активно входить в розумовий процес і займається плануванням власної навчально-пізнавальної діяльності. Центральне місце в адаптивній
} 
ISSN: 2414-0325. Open educational e-environment of modern University, special edition (2019)

системі навчання займає учень 3 його індивідуальними особливостями: біологічними задатками і здібностями, специфікою організації розумового процесу, рівнем активності і самостійності в практичній і пізнавальній діяльності, також працездатністю і т.д. Результатом даної системи стає якісна зміна його індивідуальних особливостей. Активна самостійність учня в процесі пізнавальної діяльності сприяє розвитку особистісних якостей, формування умінь інтелектуального і духовного саморозвитку, а також самопізнання особистості учня. Таким чином, адаптивна система навчання спрямована на формування компетенції особистісного самовдосконалення.

Ключові слова: адаптивна система навчання; традиційна система навчання; освіта; педагогіка; психологія; методи адаптивної системи навчання 